\title{
Evaluation of Chemical Properties, Biological Activities and Ethnomedicinal uses of Cladostemon kirkii
}

\author{
Alfred Maroyi
}

\author{
Department of Botany, University of Fort Hare, Private Bag X1314, Alice 5700, South Africa
}

\begin{abstract}
Cladostemon kirkii (Oliv.) Pax \& Gilg is a shrub or a small tree widely used as traditional medicine in tropical Africa. This study is aimed at evaluating the chemical properties, biological activities and ethnomedicinal uses of $C$. kirkii. Results of the current study are based on data derived from several online databases such as Scopus, Google Scholar, PubMed and Science Direct, and pre-electronic sources such as scientific publications, books, dissertations, book chapters and journal articles. The articles published between 1960 and 2019 were used in this study. This study revealed that the bark, leaf, root and stem infusion and/or decoction of $C$. kirkii are mainly used as traditional medicines for boils, colds, gastro-intestinal problems, hypertension, ophthalmia, rheumatism, sexual dysfunction, abdominal pains, sexually transmitted infections, sores and wounds. Phytochemical compounds identified from the species include mearnsitrin, myricitrin, kaempferol-5-rhamnoside, kaempferin, kaempferol 3-gluco-7-rhamnoside, quercetin 3,7dirhamnoside, quercetin 3-gluco-7-rhamnoside, choline, 3-hydroxyprolinebetaine and tetramethylammonium. Cladostemon kirkii should be subjected to detailed phytochemical, pharmacological and toxicological evaluations aimed at correlating its medicinal uses with its phytochemistry and pharmacological properties.
\end{abstract}

Keywords: Capparaceae, Cladostemon kirkii, indigenous pharmacopeia, traditional medicine.

\section{INTRODUCTION}

Cladostemon kirkii (Oliv.) Pax \& Gilg is a shrub or a small tree belonging to the Capparaceae or caper family. Over the years, there has been confusion concerning the delimitation of Brassicaceae, Capparaceae and Cleomaceae families. Some researchers such as Glen [1] placed C. kirkii in Brassicaceae family, following an all-inclusive Brassicaceae family concept proposed by Angiosperm Phylogeny Group [2,3] and Judd et al. [4,5]. Thus, phylogenetic relationships of Brassicaceae, Capparaceae and Cleomaceae families using the chloroplast regions ndhF, trnL-trnF, matK, and rbcL supported the monophyly of the three closely related families [6-12]. Hall et al. [6] and Hall [10] argued that species habit, fruit characteristics, floral symmetry, stamen number, leaf type and fruit type are important morphological characteristics which can be used to place different species into the three families. The genus Cladostemon A. Braun \& Vatke is a monotypic genus confined to tropical Africa [13,14]. The genus name "Cladostemon" is a contraction of two Greek words "klados" and "stemon", which translate to "branch" and "stamen", respectively, in reference to branched stamens that branch off a long and conspicuous androphore which, holds the gynophore with the ovary at its tip [15]. The specific name "kirkii" honours Sir John Kirk (1832 - 1922), a Scottish

*Address correspondence to this author at the Department of Botany, University of Fort Hare, Private Bag X1314, Alice 5700, South Africa;

Tel/Fax: 0027719600326; E-mail: amaroyi@ufh.ac.za physician, naturalist and companion of the explorer David Livingstone, a British administrator in Zanzibar who recorded and collected the tree species in the Tete district of Mozambique [1]. The English common names of $C$. kirkii are "three-finger bush" and "Tongakieri". The synonyms associated with the name $C$. kirkii include Cladostemon paxianus Gilg and Euadenia kirkii Oliv. [16-18].

Cladostemon kirkii is a shrub or small deciduous tree, seldom taller than 10 metres [19-21]. Cladostemon kirkii has smooth, rather soft branches and a brittle trunk with yellow-grey bark furrowed horizontally. The leaves of $C$. kirkii are shiny, trifoliate, elliptic to obovate in shape, leathery to almost succulent with minute and inconspicuous stipules. The leaf margins are untoothed but in young leaves they are frequently undulating. The flowers are axillary and solitary, borne in terminal spikes or clusters and sweetly scented, with a turf of spreading whitish stamens. The fruits are pendulous, globose with a hard, pale brown shell, borne on thick, jointed stalk with a pervasive unpleasant odour when picked. The seeds of C. kirkii are slightly compressed, pear-shaped to kidney-shaped. Cladostemon kirkii has been recorded in sandy soils in hot areas, bushveld, dry open sandy woodland, secondary scrub, thicket, coastal and sand forest. Cladostemon kirkii has been recorded in the Democratic Republic of Congo (DRC), Eswatini, Kenya, Malawi, Mozambique, South Africa, Tanzania, Zambia and Zimbabwe at an altitude ranging from $15 \mathrm{~m}$ to $800 \mathrm{~m}$ above sea level [22-30]. The leaves of $C$. 
kirkii are browsed by game and livestock [21]. Within its geographical distributional range, C. kirkii is cultivated as shade, an ornamental and decorative garden plant for frost-free areas [31] while the species is also occasionally cultivated in European gardens as a garden curiosity [32]. The roots of $C$. kirkii are eaten during times of famine in Tanzania [33]. The roots of $C$. kirkii are traded as herbal medicine in informal herbal medicine markets in the KwaZulu-Natal and Mpumalanga provinces in South Africa [34-37]. Cladostemon kirkii is cultivated in home gardens in the KwaZulu-Natal province in South Africa as a source of traditional medicines [38]. Cladostemon kirkii is one of the important medicinal plants in tropical Africa and the species is included in the book "Plant resources of tropical Africa 11(2): Medicinal plants 2", a photographic guide to the most commonly used medicinal plants in tropical Africa [39]. Thus, the aim of this review is to provide an integrated and detailed appraisal of the existing knowledge on the chemical properties, biological activities and ethnomedicinal uses of $C$. kirkii.

\section{Medicinal uses}

The bark, leaf, root and stem infusion and/or decoction of $C$. kirkii are mainly used as traditional medicines for boils, colds, gastro-intestinal problems, hypertension, ophthalmia, rheumatism, sexual dysfunction, abdominal pains, sexually transmitted infections, sores and wounds (Table 1; Figure 1). In South Africa, the roots of $C$. kirkii are mixed with those

Table 1: Medicinal uses of Cladostemon kirkii

\begin{tabular}{|c|c|c|c|}
\hline Medicinal use & Parts used & Country & Reference \\
\hline Abdominal pains & Root infusion and/or decoction taken orally & Mozambique & [45-47] \\
\hline Abscesses & Leaf infusion applied topically & Tanzania & [48] \\
\hline Blood purifier & Root decoction taken orally & Eswatini & [49] \\
\hline Boils & $\begin{array}{l}\text { Roots mixed with those of Commiphora zanzibarica (Baill.) Engl. } \\
\text { and applied topically }\end{array}$ & South Africa & {$[24,40]$} \\
\hline Cancer & Root infusion taken orally & Eswatini & [50] \\
\hline Ceremonial use & Whole plant & Mozambique & [1] \\
\hline Colds & Root infusion and/or decoction taken orally & Mozambique & {$[45,47]$} \\
\hline $\begin{array}{l}\text { Gastro-intestinal } \\
\text { problems (diarrhoea } \\
\text { and stomachache) }\end{array}$ & Root maceration taken orally & Mozambique & {$[47,51]$} \\
\hline Hernia & Leaf infusion taken orally & Tanzania & [52] \\
\hline Hypertension & Bark, root and stem maceration taken orally & South Africa & {$[41,53]$} \\
\hline Hypertension & $\begin{array}{c}\text { Roots mixed with leaves of Aloe marlothii A. Berger and stems of } \\
\text { Sarcophyte sanguinea Sparrm., and taken orally }\end{array}$ & South Africa & [41] \\
\hline Menstrual problems & Leaf decoction taken orally & Tanzania & [52] \\
\hline Ophthalmia & Leaf infusion applied topically & Mozambique & {$[1,33]$} \\
\hline Rheumatism & Leaf and root infusion and/or maceration applied topically & Mozambique & {$[33,54]$} \\
\hline Sexual dysfunction & Root infusion and/or decoction taken orally & Mozambique & {$[45,47]$} \\
\hline $\begin{array}{l}\text { Sexually transmitted } \\
\text { infections }\end{array}$ & Root infusion and/or decoction taken orally & $\begin{array}{l}\text { Mozambique and } \\
\text { South Africa }\end{array}$ & {$[45,47,55,56]$} \\
\hline Sores and wounds & Leaf and root infusion and/or decoction applied topically & $\begin{array}{l}\text { Eswatini, Kenya, } \\
\text { South Africa and } \\
\text { Tanzania }\end{array}$ & {$[33,38,48,49]$} \\
\hline Sores & $\begin{array}{c}\text { Roots mixed with those of Elephantorrhiza elephantina (Burch.) } \\
\text { Skeels and Sarcophyte sanguinea, bulb of Drimia delagoensis } \\
\text { (Baker) Jessop and whole plant parts of Ranunculus multifidus } \\
\text { Forssk., and applied topically }\end{array}$ & South Africa & {$[33,42,43]$} \\
\hline Sores & $\begin{array}{l}\text { Roots mixed with those of Elephantorrhiza elephantina, Sarcophyte } \\
\text { piriei Hutch., bark of Ficus sur Forssk., leaves of Senecio } \\
\text { serratuloides DC., bulb of Drimia delagoensis and whole plant parts } \\
\text { of Ranunculus multifidus, and applied topically }\end{array}$ & South Africa & {$[43,44]$} \\
\hline Sores & $\begin{array}{c}\text { Roots mixed with those of Elephantorrhiza elephantina, Sarcophyte } \\
\text { piriei, bulb of Drimia delagoensis and whole plant parts of } \\
\text { Ranunculus multifidus }\end{array}$ & South Africa & {$[43,44]$} \\
\hline Swellings & Leaf infusion applied topically & Tanzania & [52] \\
\hline
\end{tabular}




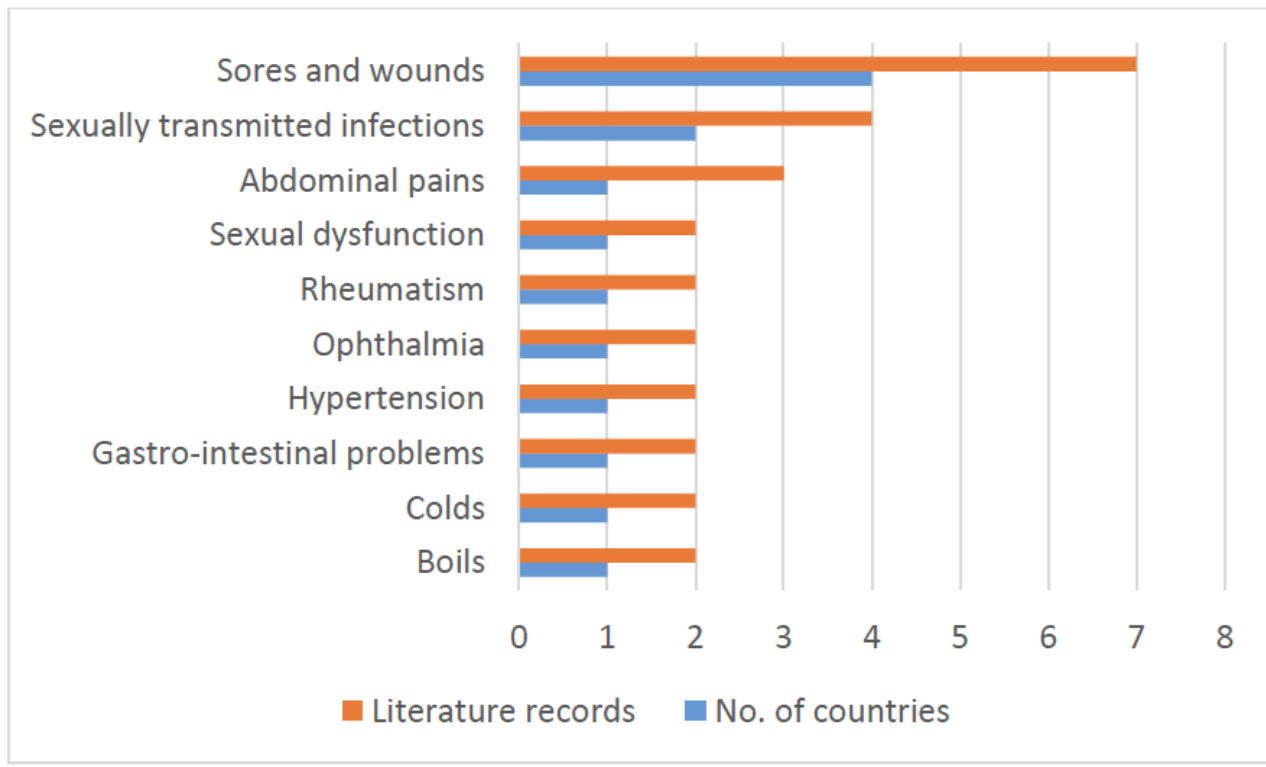

Figure 1: Medicinal applications of Cladostemon kirkii derived from literature records.

of Commiphora zanzibarica (Baill.) Engl. as traditional medicine for boils $[24,40]$. The roots of $C$. kirkii are mixed with leaves of Aloe marlothii A. Berger and stems of Sarcophyte sanguinea Sparrm. are used as traditional medicine for hypertension [41]. The roots of C. kirkii are mixed with those of Elephantorrhiza elephantina (Burch.) Skeels and Sarcophyte sanguinea, bulb of Drimia delagoensis (Baker) Jessop and whole plant parts of Ranunculus multifidus Forssk. and applied topically on sores $[42,43]$. Alternatively, the roots of C. kirkii are mixed with those of Elephantorrhiza elephantina, Sarcophyte piriei Hutch., bark of Ficus sur Forssk., leaves of Senecio serratuloides DC., bulb of Drimia delagoensis and whole plant parts of Ranunculus multifidus, and applied topically on sores $[43,44]$. The roots of $C$. kirkii are also mixed with those of Elephantorrhiza elephantina, Sarcophyte piriei, bulb of Drimia delagoensis and whole plant parts of Ranunculus multifidus and used as traditional medicine for sores $[43,44]$.

\section{Phytochemical Composition and Pharmacological Properties}

From an extract of the leaves of C. kirkii, Bombardelli et al. [57] isolated flavonoids such as mearnsitrin, myricitrin, kaempferol-5-rhamnoside, kaempferin, kaempferol 3-gluco-7-rhamnoside, quercetin 3,7-dirhamnoside and quercetin 3-gluco-7rhamnoside (Table 2). Flavonoids possess antiallergic, antibacterial, anticancer, antidiabetic, antifungal, antiinflammatory, antileukemic, anti-mutagenic, antioxidant, antiulcer, antiviral, cardioprotective, hepatoprotective, immune system promoting, skin protective and vasodilator effects [58-64]. McLean et al. [65] identified choline, 3-hydroxyprolinebetaine and tetramethylammonium from the aerial parts and branches of C. kirkii. Loontjens [66] argued that quaternary ammonium compounds are potent biocides widely used in medical applications, cosmetics, disinfectants, surfactants and solvents. The leaves of C. kirkii also yielded $6.8 \%$ proteins and $3.8 \%$ lipids $[67,68]$.

De Wet et al. [38] evaluated the antibacterial activities of crude extracts of $C$. kirkii roots against Escherichia coli and Staphylococcus aureus using the micro dilution method. The extract exhibited activities against tested pathogens [38]. Similarly, Pereira et al. [69] evaluated the antibacterial activities of methanol extracts of C. kirkii roots against Staphylococcus aureus, Enterococcus faecalis, Bacillus subtilis, Salmonella typhimurium and Pseudomonas aeruginosa using the micro dilution method. The extract exhibited activities against tested pathogens [69]. Ramulondi [70] and Ramulondi et al. [71] evaluated the toxicity activities of dichloromethane: methanol and aqueous extract of $C$. kirkii roots using the brine shrimp assay and the Ames test. The authors also assessed the cytotoxicity activities of aqueous and organic extracts of $C$. kirkii in combinations with Aloe marlothii leaves and Sarcostemma sanguena stems using the sum of the fractional inhibitory concentration ( $\mathrm{FIC}$ ), which allowed the classification of the type of the cytotoxicity. Both extracts were categorized as non-toxic as the mortality rate was less than $50 \%$ [72]. Both extracts were also categorized as non-mutagenic against Salmonella typhimurium bacterial strains, TA98 and 
Table 2: Phytochemical Composition of Cladostemon kirkii

\begin{tabular}{|c|c|c|}
\hline Phytochemical compound & Plant part & Reference \\
\hline Mearnsitrin & Leaves & {$[57]$} \\
\hline Myricitrin & Leaves & [57] \\
\hline Kaempferol-5-rhamnoside & Leaves & [57] \\
\hline Kaempferin & Leaves & {$[57]$} \\
\hline Kaempferol 3-gluco-7-rhamnoside & Leaves & {$[57]$} \\
\hline Quercetin 3,7-dirhamnoside & Leaves & {$[57]$} \\
\hline Quercetin 3-gluco-7-rhamnoside & Leaves & {$[57]$} \\
\hline Choline & Aerial parts and branches & [65] \\
\hline 3-hydroxyprolinebetaine & Aerial parts and branches & [65] \\
\hline Tetramethylammonium & Aerial parts and branches & [65] \\
\hline Proteins (\%) & Leaves & {$[67,68]$} \\
\hline Lipids (\%) & Leaves & {$[67,68]$} \\
\hline
\end{tabular}

TA100. Plant combinations resulted in additive, antagonistic and non-interactive effects. The plant combinations tested in the Ames test resulted in noninteractive effects towards both Salmonella typhimurium strains $[70,71]$.

\section{CONCLUSION}

Cladostemon kirkii is widely used as herbal medicine throughout its distributional range in tropical Africa. Documentation of its ethnopharmacological properties is important as this information is required for further research on the species. The present study showed that there are still some research gaps in the phytochemistry, pharmacological and toxicological properties of the species. Further rigorous research is required aimed at evaluating the phytochemical properties of the different plant parts used as sources of traditional medicines.

\section{CONFLICT OF INTEREST}

No conflict of interest is associated with this work.

\section{REFERENCES}

[1] Glen HF. Cladostemon kirkii (Oliv.) Pax \& Gilg. South African National Biodiversity Institute, Cape Town; 2007. Available on: http://pza.sanbi.org/cladostemon-kirkii, accessed on 24 March 2020

[2] Angiosperm Phylogeny Group. An ordinal classification for the families of flowering plants. Annals Missouri Bot Gard 1998; 85: 531-53. https://doi.org/10.2307/2992015

[3] Angiosperm Phylogeny Group. An update of the Angiosperm Phylogeny Group classification for the orders and families of flowering plants: APG II. J Linnean Soc Bot 2003; 141: 399436.

https://doi.org/10.1046/j.1095-8339.2003.t01-1-00158.x
[4] Judd WS, Sanders RW, Donoghue MJ. Angiosperm family pairs: Preliminary phylogenetic analyses. Harvard Papers Bot 1994; 5: 1-51.

[5] Judd WS, et al. Plant systematics: A phylogenetic approach. Massachusetts: Sinauer Associates; 2007.

[6] Hall JC, Sytsma KJ, Iltis HH. Phylogeny of Capparaceae and Brassicaceae based on chloroplast sequence data. American J Bot 2002; 89(11): 1826-42. https://doi.org/10.3732/ajb.89.11.1826

[7] Hall JC, Iltis HH, Sytsma KJ. Molecular phylogenetics of core Brassicales, placement of orphan genera Emblingia, Forchhammeria, Tirania, and character evolution. Syst Bot 2004; 29: 654-69. https://doi.org/10.1600/0363644041744491

[8] Simpson MG. Plant systematics. Massachusetts: Elsevier Academic Press; 2006.

[9] Heywood $\mathrm{VH}$, et al. Flowering plants of the world. Ontario: Firefly Press; 2007.

[10] Hall JC. Systematics of Capparaceae and Cleomaceae: An evaluation of the generic delimitations of Capparis and Cleome using plastid DNA sequence data. Botany 2008; 86: 682-96. https://doi.org/10.1139/B08-026

[11] Angiosperm Phylogeny Group. An update of the Angiosperm Phylogeny Group classification for the orders and families of flowering plants: APG III. J Linnean Society Bot 2009; 161: 105-21. https://doi.org/10.1111/j.1095-8339.2009.00996.x

[12] Iltis $\mathrm{HH}$, et al. Studies in the Cleomaceae I: On the separate recognition of Capparaceae, Cleomaceae, and Brassicaceae. Annals Missouri Bot. Gard 2011; 98: 28-36. https://doi.org/10.3417/2007017

[13] Kers LE. Capparidaceae (Capparaceae). In Edwards S Tadesse M, Demissew S, Hedberg I (Editors), Flora of Ethiopia and Eritrea vol 2(1). Uppsala: Swedish Science Press; 2000, pp. 74-120.

[14] Byng JW. The flowering plants handbook: A practical guide to families and genera of the world. New York: Plant Gateway Ltd; 2014.

[15] Palmer E and Pitman N. Trees of southern Africa, covering all known indigenous species in the Republic of South Africa, South-West Africa, Botswana, Lesotho and Swaziland. Cape Town: Balkema; 1972. 
[16] Wild H. Capparidaceae. In Exell AW, Wild H (Editors), Flora Zambesiaca 1. London: Crown Agents for Oversea Governments and Administrations; 1960, pp. 194-245.

[17] Elfers RA, Grahama DG, Dewolf P. Capparidaceae. In Hubbard CE, Milne-Redhead E (Editors), Flora of Tropical East Africa. London: Crown Agents for Oversea Governments and Administrations; 1964, pp. 1-88.

[18] Killick DJB. Cladostemon and Bachmannia. In Codd LE, De Winter B, Killick DJB (Editors), Flora of southern Africa 13. Pretoria: Botanical Research Institute; 1970, pp. 140-3.

[19] Palgrave MC. Keith Coates Palgrave trees of southern Africa. Cape Town: Struik Publishers; 2002.

[20] Lovett JC, et al. Field Guide to the moist forest trees of Tanzania. London: Frontier Publishing; 2006.

[21] Van Wyk B, Van Wyk P. Field guide to trees of southern Africa. Cape Town: Struik Nature; 2013.

[22] Von Breitenbach F. The indigenous trees of southern Africa. Pretoria: Government Printer; 1965.

[23] Drummond RB. A list of trees, shrubs and woody climbers indigenous or naturalised in Rhodesia. Kirkia 1975; 10: 22985.

[24] Pooley ES. The complete field guide to trees of Natal, Zululand and Transkei. Durban: Natal Flora Publications Trust; 1993.

[25] Beentje HJ. Kenya trees, shrubs and lianas. Nairobi: National Museums of Kenya; 1994.

[26] Germishuizen G, Meyer NL. Plants of southern Africa: An annotated checklist. Pretoria: Strelitzia 14, National Botanical Institute; 2003.

[27] Da Silva MC, Izidine S, Amude AB. A preliminary checklist of the vascular plants of Mozambique. Pretoria: Southern African Botanical Diversity Network Report No. 30; 2004.

[28] Mapaura A, Timberlake J. A checklist of Zimbabwean vascular plants. Pretoria: Southern African Botanical Diversity Network Report No. 33; 2004.

[29] Strugnell AM. A checklist of the Spermatophytes of Mount Mulanje, Malawi. Meise: Scripta Botanica Belgica 34, National Botanic Garden of Belgium; 2006.

[30] Burrows JE, et al. Trees and shrubs of Mozambique. Cape Town: Publishing Print Matters (Pty); 2018.

[31] Johnson D, Johnson S. Down to earth: Gardening with indigenous trees. Cape Town: Struik Publishers; 2002.

[32] Cullen J, Knees SG, Cubey HS. The European garden flora flowering plants: A manual for the identification of plants cultivated in Europe, both out-of-doors and under glass. Cambridge: Cambridge University Press; 2011.

[33] Lemmens RHMJ. Cladostemon kirkii (Oliv.) Pax \& Gilg. In Schmelzer GH, Gurib-Fakim A (Editors), Plant resources of tropical Africa 11(2): Medicinal plants 2. Wageningen: Backhuys Publishers; 2013, pp. 50-1.

[34] Cunningham AB. African medicinal plants: Setting priorities at the interface between conservation and primary health care. Paris: People and Plants working paper 1. UNESCO; 1993.

[35] Botha J, Witkowski ETF, Cock J. A review of nurseries as conservation or social forestry outreach tools. Int J Biod Sci Manag 2004; 1: 33-51. https://doi.org/10.1080/17451590509618078

[36] Botha J. The viability of conservation and social forestry outreach nurseries in South Africa. $\mathrm{PhD}$ thesis. Johannesburg: University of the Witwatersrand; 2006.

[37] Botha J, Witkowski ETF, Shackleton CM. Factors influencing prices of medicinal plants traded in the Lowveld, South Africa. Int J Sustain Develop World Ecol 2007; 14(5): 450-69. https://doi.org/10.1080/13504500709469745

[38] De Wet $\mathrm{H}$, et al. An ethnopharmacological investigation of home grown plants used for treating diarrhoea and wound infections in the Mbazwana area, Maputaland. S Afr J Bot 2008; 74: 365-6.

https://doi.org/10.1016/j.sajb.2008.01.050

[39] Schmelzer GH, Gurib-Fakim A. Plant resources of tropical Africa 11(2): Medicinal plants 2. Wageningen: Backhuys Publishers; 2013.

[40] Hutchings A, et al. Zulu medicinal plants. An inventory. Pietermaritzburg: University of Natal Press; 1996.

[41] De Wet $\mathrm{H}$, Ramulondi M, Ngcobo ZN. The use of indigenous medicine for the treatment of hypertension by a rural community in northern Maputaland, South Africa. S Afr J Bot 2016; 103: 78-88. https://doi.org/10.1016/j.sajb.2015.08.011

[42] Nciki S. Validating the traditional use of medicinal plants in Maputaland to treat skin diseases. MSc Dissertation. Johannesburg: University of the Witwatersrand; 2015.

[43] Maroyi A. Elephantorrhiza elephantina: Traditional uses, phytochemistry, and pharmacology of an important medicinal plant species in southern Africa. Evidence-Based Compl Alt Med 2017; article ID 6403905.

\section{https://doi.org/10.1155/2017/6403905}

[44] De Wet H, Nciki S, Van Vuuren SF. Medicinal plants used for the treatment of various skin disorders by a rural community in northern Maputaland, South Africa. J Ethnobiol Ethnomed 2013; 9: 51.

https://doi.org/10.1186/1746-4269-9-51

[45] Ribeiro A, et al. Ethnobotanical survey in Canhane village, district of Massingir, Mozambique: Medicinal plants and traditional knowledge. J Ethnobiol Ethnomed 2010; 6: 33. https://doi.org/10.1186/1746-4269-6-33

[46] Conde P, et al. The botanic mission to Mozambique (1942 1948): Contributions to the knowledge of the medicinal flora of Mozambique. História Ciências Saúde Mang Rio Janeiro 2014; $21: 2$

https://doi.org/10.1590/S0104-59702014000200007

[47] Monjane J. Secondary metabolites from Mozambican plants. PhD Thesis. Lund: Lund University; 2017.

[48] Sakamoto K. Local traditional knowledge and ethics in Southeast Tanzania: Mzee Rashid Litunungu's contribution on history, livelihood, and plant use research. J Faculty Int Stud Utsunomiya Univ 2018. 45: 37-46.

[49] Singwane SS, Shabangu N. An examination of the utilization and management of natural woodlands in Swaziland: A case of ka Bhudla community. J Sustain Develop Afr 2012; 14: 1.

[50] Long C. Swaziland's flora: Siswati names and uses. Mbambane, Swaziland: Swaziland National Trust Commission; 2005. Available from: http://www .sntc.org.sz/index.asp, accessed on 14 Febreuary 2020.

[51] Bruschi $P$, et al. Traditional healers and laypeople: $A$ qualitative and quantitative approach to local knowledge on medicinal plants in Muda (Mozambique). J Ethnopharmacol 2011; 138: 543-63.

https://doi.org/10.1016/j.jep.2011.09.055

[52] Sakamoto K. Herbal medicine use and diversity/sharing of the knowledge: The case of Rutamba villages in Lindi region, southeast Tanzania. J Faculty Int Stud Utsunomiya Univ 2019. 48: 15-30.

[53] Balogun FO, Ashafa AOT. A review of plants used in South African traditional medicine for the management and treatment of hypertension. Planta Med 2019; 85: 312-34. https://doi.org/10.1055/a-0801-8771

[54] Turner Q. Medicinal plants of Maputaland. Sabonet News 2002; 7(2): 114-15.

[55] De Wet H, Van Vuuren SF. Medicinal plants used for the treatment of sexually transmitted infections by lay people in northern Maputaland, KwaZulu-Natal Province, South Africa. S Afr J Bot 2012; 78: 12-20. https://doi.org/10.1016/j.sajb.2011.04.002 
[56] Mulaudzi RB. Pharmacological evaluation of medicinal plants used by Venda people against venereal and related diseases. PhD Thesis. Pietermaritzburg: University of KwaZulu-Natal; 2012.

[57] Bombadelli E, Gabetta B, Mustica G. Plants of Mozambique II. Flavinoids of Cladostemon kirkii. Fitoterapia 1973; 44: 91.

[58] Sharma DK. Pharmacological properties of flavonoids (including flavonolignans) and integration of petrocrops with drug development from plants. J Sci Industrial Res 2006; 65: 477-84.

[59] Tapas AP, Sakarkar DM, Kakde RB. Flavonoids as nutraceuticals: A review. Trop J Pharmaceut Res 2008; 7(3): 1089-99. https://doi.org/10.4314/tjpr.v7i3.14693

[60] Kumar S, Pandey AK. Chemistry and biological activities of flavonoids: An overview. Sci World J 2013; article 162750. https://doi.org/10.1155/2013/162750

[61] Panche AN, Diwan AD, Chandra SR. Flavonoids: An overview. J Nutr Sci 2016; 5: e47. https://doi.org/10.1017//ns.2016.41

[62] Juca MM, et al. Flavonoids: biological activities and therapeutic potential. Nat Prod Res 2018; 34(5): 692-705. https://doi.org/10.1080/14786419.2018.1493588

[63] Sharma A, et al. Phytochemical and pharmacological properties of flavonols. eLS 2018; 1: 1-12. https://doi.org/10.1002/9780470015902.a0027666

[64] Tungmunnithum D, et al. Flavonoids and other phenolic compounds from medicinal plants for pharmaceutical and medical aspects: An overview. Medicine 2018; 5(3): 93. https://doi.org/10.3390/medicines5030093
[65] McLean WFH, Blunden G, Jewers K. Quaternary ammonium compounds in the Capparaceae. Biochem Syst Ecol 1996; 24(5): 427-34. https://doi.org/10.1016/0305-1978(96)00044-0

[66] Loontjens JA. Quaternary ammonium compounds. In Moriarty F, Zaat SAJ, Busscher HJ (Editors), Biomaterials associated infection. New York: Springer Science and Business Media; 2013, pp. 379-404. https://doi.org/10.1007/978-1-4614-1031-7 15

[67] Gaynor D. Foraging and feeding behaviour of Chacma baboons in a woodland habitat. PhD Thesis, Durban: University of Natal; 1994.

[68] Wilson A-L, Downs CT. Fruit nutritional composition and nonnutritive traits of indigenous South African tree species. S Afr J Bot 2012; 78: 30-6. https://doi.org/10.1016/j.sajb.2011.04.008

[69] Pereira $\mathrm{F}$, et al. Evaluation of the antibacterial activity of some African medicinal plants. Planta Med 2015; 81: 108 https://doi.org/10.1055/s-0035-1565485

[70] Ramulondi M. Toxicology and herb-drug interaction of selected anti-hypertension plants used by lay persons in northern Kwazulu-Natal (South Africa). MSc Dissertation. KwaDlangezwa: University of Zululand; 2017.

[71] Ramulondi M, De Wet H, Van Vuuren S. Toxicology of medicinal plants and combinations used in rural northern KwaZulu-Natal (South Africa) for the treatment of hypertension. J Herbal Med 2019; 16: 100251. https://doi.org/10.1016/j.hermed.2018.12.001

[72] Bussmann RW, et al. Toxicity of medicinal plants used in traditional medicine in Northern Peru. J Ethnopharmacol 2011; 137: 121-40. https://doi.org/10.1016/j.jep.2011.04.071

DOI: https://doi.org/10.29169/1927-5951.2020.10.05.3

(C) 2020 Alfred Maroyi; Licensee SET Publisher.

This is an open access article licensed under the terms of the Creative Commons Attribution Non-Commercial License (http://creativecommons.org/licenses/by-nc/3.0/) which permits unrestricted, non-commercial use, distribution and reproduction in any medium, provided the work is properly cited. 